\title{
Sleep disorders in psoriasis
}

\section{Zaburzenia snu w łuszczycy}

Julia Nowowiejska, Anna Baran, Iwona Flisiak

Department of Dermatology and Venereology, Medical University of Bialystok, Poland

Klinika Dermatologii i Wenerologii, Uniwersytet Medyczny w Białymstoku, Polska

Dermatol Rev/Przegl Dermatol 2020, 107, 273-280

DOI: https://doi.org/l 0.5 I /4/dr.2020.97780

\author{
CORRESPONDING AUTHOR/ \\ ADRES DO KORESPONDENCJI: \\ dr hab. med. Anna Baran \\ Klinika Dermatologii \\ i Wenerologii \\ Uniwersytet Medyczny \\ ul. Żurawia 14 \\ 15-540 Białystok \\ e-mail: anna.baran@umb.edu.pl
}

\begin{abstract}
Psoriasis is a chronic inflammatory skin disease affecting 2-4\% of general population. Skin lesions may be accompanied by pruritus or pain, what may cause difficulties in daily functioning, and also disturb sleep. Many patients suffer from depression, which is often accompanied by sleep disorders, usually insomnia. Psoriasis is also strongly associated with metabolic syndrome and obesity, but also with obstructive sleep apnea syndrome. Research also shows that patients with psoriasis more frequently suffer from restless leg syndrome. Sleep disorders lead to significant deterioration of patients' quality of life, which is already decreased by the disease itself. Therefore, it is advisable to screen patients with psoriasis for sleep disorders, and introduce adequate treatment early during the course of the disease.
\end{abstract}

\section{STRESZCZENIE}

Łuszczyca jest przewlekłą chorobą zapalną skóry, która dotyczy 2-4\% populacji. Zmiany skórne mogą przebiegać ze świądem, a nawet bólem, co może utrudniać codzienne funkcjonowanie, w tym sen. Duża część pacjentów choruje również na depresję, której nierzadko towarzyszą zaburzenia snu, zwykle w postaci bezsenności. Łuszczyca ma liczne powiązania z zespołem metabolicznym, otyłością, a także zespołem obturacyjnego bezdechu sennego. Istnieją doniesienia o częstszym występowaniu zespołu niespokojnych nóg u chorych na łuszczycę. Zaburzenia snu prowadzą dodatkowo do istotnego pogorszenia jakości życia pacjenta. Dlatego celowe wydaje się przeprowadzanie u pacjentów chorujących na łuszczycę badań przesiewowych w kierunku zaburzeń snu, co umożliwi wczesne włączenie odpowiedniego leczenia.

Key words: psoriasis, sleep, sleep disturbances, obstructive sleep apnea, restless leg syndrome.

Słowa kluczowe: łuszczyca, sen, zaburzenia snu, obturacyjny bezdech senny, zespół niespokojnych nóg. 


\section{INTRODUCTION}

Psoriasis is a chronic inflammatory skin disease that affects $2-4 \%$ of the population [1,2]. Currently, this dermatosis is perceived as a systemic disease characterized by high comorbidity and increased mortality $[1,2]$. The disease causes of not only physical but also mental problems [3]. Studies confirm that psoriasis reduces the quality of life of patients in all age groups, but also of patients' families [2-4]. That is a result of not only the appearance of the skin lesions, but also the time consumed on visits to doctors and treatment [4]. Data from the literature indicate that deterioration of quality of life of patients with psoriasis is so significant that it is comparable to that associated with serious internal diseases, such as cancer, arthritis, hypertension, heart disease or diabetes $[4,5]$. Psoriasis is characterized by a complex pathogenesis as well as a multitude of clinical presentations, which translates into variable treatment methods and their different effectiveness, and thus patient comfort [6].

According to the DSM V (Diagnostic and Statistical Manual of Mental Disorders) classification, sleep disorders are divided into insomnia disorders, hypersomnolence disorders, narcolepsy, parasomnias (including restless legs syndrome (RLS)) and sleeprelated breathing disorders (including obstructive sleep apnea syndrome (OSAS) [7, 8] (table 1). Studies confirm the importance of this issue, especially for patients suffering from chronic diseases. Patients free of sleep disorders have a healthy life expectancy (HLE) up to 6 years longer, as well as up to 3 years longer chronic disease-free life expectancy than those with sleep disorders [9]. In addition to a detailed medical examination, there are simple, standardized questionnaires to detect and assess severity of sleep disorders. The most commonly used tool is the Epworth sleepiness scale - a questionnaire that may be answered by unattended patient and that is currently used to assess various sleep disorders (especially severity of daytime sleepiness). It was originally designed to assess patients with OSAS [10, 11]. Another very popular method of assessing sleep disorders, especially qualitative, is the Pittsburgh Sleep Quality Questionnaire, which includes questions about sleep habits during the last month [12]. Other specific sleep disorders can also be assessed using validated questionnaires, taking into account their severity or risk of occurrence.

Skin lesions in the course of psoriasis may be associated with pruritus or even pain, that may hinder daily functioning, including sleep $[3,13,14]$. A large proportion of patients feel stigmatized and suffer from depression, often accompanied by sleep disorders, usually in the form of insomnia [2, 7, 15-17]. Both itching and depressive symptoms seem to be the

\section{WPROWADZENIE}

Łuszczyca jest przewlekłą chorobą zapalną skóry, która dotyczy $2-4 \%$ populacji $[1,2]$. Obecnie dermatozę tę traktuje się jako schorzenie ogólnoustrojowe, cechujące się wysoką współchorobowością i zwiększoną śmiertelnością $[1,2]$. Łuszczyca jest przyczyną nie tylko dolegliwości fizycznych, lecz także psychicznych [3]. Badania potwierdzają, że choroba powoduje obniżenie jakości życia we wszystkich grupach wiekowych, również wśród rodzin pacjentów [2-4]. Przyczynia się do tego nie tylko niekorzystny wygląd zmian skórnych, lecz także czas, jaki pochłaniają wizyty lekarskie i stosowane leczenie [4]. Dane z piśmiennictwa wskazują, że obniżenie jakości życia chorych na łuszczycę jest tak duże, że jest porównywalne z występującym w poważnych chorobach internistycznych, takich jak choroba nowotworowa, choroby zapalne stawów, nadciśnienie, choroby serca czy cukrzyca [4, 5]. Łuszczyca charakteryzuje się złożoną patogenezą i mnogością obrazów klinicznych, co przekłada się na wielość metod leczenia i ich zróżnicowaną skuteczność, a w konsekwencji komfort pacjentów [6].

Zaburzenia snu zgodnie z klasyfikacją DSM V (Diagnostic and Statistical Manual of Mental Disorders) dzieli się na: polegające na bezsenności, na nadmiernej senności, narkolepsja, parasomnie [do których należy zespół niespokojnych nóg (restless legs syndrome - RLS)] i zaburzenia oddychania w czasie snu [do których należy zespół obturacyjnego bezdechu sennego (obstructive sleep apnea syndrome - OSAS)] [7, 8] (tab. 1). Badania potwierdzają, jak ważne jest to zagadnienie, zwłaszcza u osób z przewlekłymi schorzeniami. Pacjenci bez zaburzeń snu mają oczekiwaną długość życia w zdrowiu (healthy life expectancy - HLE) nawet do 6 lat dłuższą, jak również do 3 lat dłuższą oczekiwaną długość życia bez chorób przewlekłych (chronic disease-free life expectancy) niż osoby z zaburzeniami snu [9]. Poza szczegółowym badaniem lekarskim istnieją łatwe do przeprowadzenia, standaryzowane kwestionariusze służące do wykrywania i oceny nasilenia zaburzeń snu. Najczęściej używanym narzędziem jest skala senności Epworth. Wykorzystuje ona kwestionariusz, który pierwotnie został skonstruowany dla pacjentów z OSAS, a obecnie jest używany do oceny różnych zaburzeń snu (zwłaszcza nasilenia senności dziennej) i może być wypełniany samodzielnie przez pacjentów [10, 11]. Innym bardzo popularnym narzędziem oceny zaburzeń snu, zwłaszcza jakościowych, jest kwestionariusz jakości snu Pittsburgh, który zawiera pytania odnoszące się do nawyków związanych ze snem w czasie ostatniego miesiąca [12]. Inne, specyficzne zaburzenia snu mogą być również oceniane za pomocą walidowanych kwestionariuszy, które biorą pod uwagę stopień nasilenia zaburzeń lub ryzyko wystąpienia.

Zmiany skórne w przebiegu łuszczycy mogą przebiegać ze świądem lub nawet bólem, co utrudnia codzienne funkcjonowanie, w tym sen $[3,13,14]$. Wielu pacjentów 
Table I. Sleep disorders categories according to DSM V

Tabela I. Podział zaburzeń snu wg DSM V

Insomnia disorders/Zaburzenia snu polegające na bezsenności

Hypersomnolence disorders/Zaburzenia snu polegające na nadmiernej senności

Narcolepsy/Narkolepsja

Sleep-related breathing disorders (including e.g. OSAS and circadian rhythm sleep-wake disorder)/Zaburzenia snu związane

z zaburzeniami oddychania w czasie snu (w tym OSAS i zaburzenia rytmu okołodobowego snu i czuwania)

Parasomnias (including restless legs syndrome)/Parasomnie (w tym zespół niespokojnych nóg)

two most important prognostic factors for poor sleep quality and insomnia in patients with psoriasis [18]. Psoriasis has also numerous connections with metabolic syndrome, and thus with obesity, which further connects this dermatosis with obstructive sleep apnea syndrome [14]. Sleep disorders are also closely related to the risk of inflammatory diseases, including psoriasis [19]. There are many studies assessing the quality of sleep in psoriasis patients $[2,3,20]$.

This paper presents current views and literature data on the relationship between psoriasis and sleep disorders.

\section{THE QUALITY OF SLEEP}

The Pittsburgh Sleep Quality Questionnaire is a useful tool for the overall assessment of sleep disorders. The PSQI (Pittsburgh Sleep Quality Index) is calculated on the basis of the questionnaire. The index is often used in studies assessing sleep in patients with psoriasis $[14,21]$. Many publications confirm the more frequent occurrence of sleep disorders, especially insomnia, in patients with psoriasis $[2,14$, 17]. As mentioned above, not only the existing skin changes contribute to disturbed sleep, but also vice versa: sleep disturbances can exacerbate psoriasis through multidirectional mechanisms: hypothalamicpituitary-adrenal axis dysregulation, immune disorders, altered melatonin secretion, increased sympathetic nervous system activity. Sleep deprivation can be even considered a kind of risk factor for psoriasis $[13,22]$. There are conflicting reports on the relationship between reduced sleep quality and severity of psoriasis lesions on the PASI scale (Psoriasis Area and Severity Index), and therefore it seems that this indicator cannot be used with certainty as a predictor of sleep disorder $[17,21]$. However, those ailments are more frequently observed in patients with psoriatic arthritis compared to patients with skin lesions only [21]. Some studies indicate a directly proportional relationship between the severity of sleep disorders and the PASI value $[17,21]$. Other reports do not confirm this relationship, moreover, it is suggested that there is no correlation between the objective PASI score and the subjective feeling of the severity ma poczucie stygmatyzacji, ma depresję, której nierzadko towarzyszą również zaburzenia snu, zwykle w postaci bezsenności [2, 7, 15-17]. Wydaje się, że świąd i objawy depresyjne to dwa najistotniejsze czynniki prognostyczne złej jakości snu i bezsenności u chorych na łuszczycę [18]. Łuszczyca ma również liczne powiązania z zespołem metabolicznym i otyłością, co dodatkowo łączy tę dermatozę z OSAS [14]. Zaburzenia snu są ściśle związane z ryzykiem wystąpienia chorób na tle zapalnym, do których również zalicza się łuszczycę [19]. Istnieje wiele badań oceniających jakość snu u chorych na łuszczycę $[2,3,20]$.

W niniejszej pracy przedstawiono aktualne poglądy $\mathrm{i}$ dane $\mathrm{z}$ piśmiennictwa na temat powiązań łuszczycy z zaburzeniami snu.

\section{JAKOŚĆ SNU}

Kwestionariusz jakości snu Pittsburgh jest przydatnym narzędziem do całościowej oceny zaburzeń snu. Na podstawie tego kwestionariusza wyliczany jest wskaźnik PSQI (Pittsburgh Sleep Quality Index), często wykorzystywany w badaniach oceniających sen u chorych na łuszczycę $[14,21]$. Wiele publikacji potwierdza częstsze występowanie zaburzeń snu u pacjentów z łuszczycą, zwłaszcza bezsenności $[2,14,17]$. Jak wspomniano, nie tylko obecne zmiany skórne przyczyniają się do zaburzeń snu, lecz także odwrotnie - zaburzenia snu mogą nasilać łuszczycę poprzez wielokierunkowe mechanizmy: dysregulację osi podwzgórze-przysadka-nadnercza, zaburzenia immunologiczne, zmienione wydzielanie melatoniny, zwiększoną aktywność współczulnego układu nerwowego. Nawet deprywacja snu może być uznawana za swego rodzaju czynnik ryzyka zachorowania na łuszczycę $[13,22]$. Istnieją sprzeczne doniesienia na temat zależności między obniżoną jakością snu a nasileniem zmian łuszczycowych w skali PASI (Psoriasis Area and Severity Index), w związku z czym wydaje się, że nie można z całą pewnością wykorzystać tego wskaźnika jako czynnika prognostycznego wystąpienia zaburzeń snu u pacjentów [17, 21]. Obserwuje się je częściej u chorych $\mathrm{z}$ łuszczycowym zapaleniem stawów $\mathrm{w}$ porównaniu $\mathrm{z}$ chorymi z zajętą wyłącznie skórą [21]. Część badań wskazuje na wprost proporcjonalną zależność stopnia nasilenia zaburzeń snu od wartości PASI $[17,21]$. Inne doniesienia 
of sleep disorders reported by patients [17, 23]. In the case of sleep abnormalities in a patient with psoriasis, there appears to be a vicious circle mechanism: psoriasis intensifies sleep disorders, which in turn reduces the patient's quality of life, increases stress, further intensifying severity of the disease. By implementing early detection of sleep disorders in psoriasis patients and introducing therapy as early as possible, the quality of life of these patients may be increased and the level of stress may be reduced in this group of patients. This can be achieved by using in-hospital or outpatient questionnaires for screening sleep disorders among patients, and then, after identifying a group requiring help, directing them to appropriate specialists.

\section{OBSTRUCTIVE SLEEP APNEA SYNDROME}

Obstructive sleep apnea syndrome is a disorder of breathing during sleep consisting in the occurrence of recurrent episodes of obstructions of the upper respiratory tract (apnea) or their narrowing (shortness of breath), while the work of the respiratory muscles remains unchanged [24, 25]. The diagnosis of OSAS can be made on the basis of clinical symptoms and risk assessment using special questionnaires (e.g. STOP BANG (Snoring, Tired, Observed, Pressure, Body mass index, Age older than 50, Neck size large, Gender - male), the Berlin questionnaire, NoSAS (Neck, Obesity, Snoring, Age, Sex)), and confirmed after a sleep test (polysomnographic or polygraphic) and assessment of the AASM criteria (American Academy of Sleep Medicine): (1) at least 15 respiratory episodes (apnea, shortness of breath, awakening associated with breathing effort) per hour of sleep, (2) RDI (Respiratory Disturbance Index, indicator of apnea, shallow breathing and awakening episodes per hour of sleep) $\geq 5$ in the person presenting at least one of the following symptoms: a) falling asleep against their own will, excessive daytime sleepiness, inefficient sleep, fatigue or insomnia, b) waking up with a feeling of stopped breath, shortness of breath or choking, c) a person sleeping with the patient reports loud snoring or sleep apnea (table 2) [24]. OSAS is strongly associated with the occurrence of obesity, which, along with male sex, large collar circumference, impaired airway patency, drinking alcohol or the use of certain drugs, is the most important risk factor for the syndrome [24, 25]. Obstructive sleep apnea increases the risk of development of cardiovascular diseases (hypertension, ischemic heart disease, arrhythmia and conduction disorders, heart failure and stroke), which, in turn, also significantly more often coexist with psoriasis [24, 25]. These disorders are a consequence of hypoxia and waking from sleep, that cause the change of physiological pathways, nie potwierdzają tego związku, ponadto sugeruje się, że brakuje zależności pomiędzy obiektywnym wynikiem w skali PASI a subiektywnym odczuciem stopnia nasilenia zaburzeń snu zgłaszanym przez pacjentów [17, 23]. Wydaje się, że w przypadku wystąpienia nieprawidłowości snu u chorego na łuszczycę działa mechanizm błędnego koła: łuszczyca wzmaga zaburzenia snu, które obniżają jakość życia pacjenta i zwiększają stres, co powoduje nasilenie choroby. Wczesne wykrycie zaburzeń snu u chorych na łuszczycę oraz wdrożenie ich leczenia może się przyczynić do poprawy jakości życia pacjentów i obniżenia poziomu stresu w tej grupie. Można to osiągnąć poprzez stosowanie w warunkach szpitalnych lub ambulatoryjnych kwestionariuszy do przesiewowej oceny zaburzeń snu w celu wyodrębnienia grupy wymagającej pomocy, a nastepnie kierowanie chorych do odpowiednich specjalistów.

\section{ZESPÓŁ OBTURACYJNEGO BEZDECHU SENNEGO}

Zespół obturacyjnego bezdechu sennego to zaburzenie oddychania w czasie snu polegające na występowaniu nawracających epizodów obturacji górnych dróg oddechowych (bezdechy) lub zwężenia dróg oddechowych (spłycenie oddychania), podczas gdy praca mięśni oddechowych pozostaje zachowana $[24,25]$. Podejrzenie OSAS można wysunąc na podstawie objawów klinicznych i oszacowania ryzyka jego wystąpienia za pomocą specjalnych kwestionariuszy [np. STOP BANG (Snoring, Tired, Observed, Pressure, Body mass index, Age older than 50, Neck size large, Gender-male), kwestionariusz berliński, NoSAS (Neck, Obesity, Snoring, Age, Sex)], a potwierdzić po wykonaniu badania snu (polisomnograficznego lub poligraficznego) oraz na podstawie kryteriów AASM (American Academy of Sleep Medicine): (1) co najmniej 15 epizodów oddechowych (bezdechy, spłycenia oddychania, przebudzenia związane z wysiłkiem oddechowym) na godzinę snu, (2) RDI (Respiratory Disturbance Index, wskaźnik liczby bezdechów, spłyceń oddychania i przebudzeń na godzinę snu) $\geq 5$ u osoby, u której występuje co najmniej jeden z następujących objawów: a) zasypianie wbrew własnej woli, nadmierna senność dzienna, nieefektywny sen, zmęczenie lub bezsenność, b) przebudzenia z uczuciem zatrzymania oddechu, duszności lub dławienia, c) osoba sypiająca z chorym stwierdza głośne chrapanie lub bezdech podczas snu (tab. 2) [24]. OSAS jest silnie związany z otyłością, która obok płci męskiej, dużego obwodu kołnierzyka, upośledzenia drożności dróg oddechowych, picia alkoholu i stosowania niektórych leków - należy do najważniejszych czynników ryzyka jego występowania $[24,25]$. Obturacyjny bezdech senny zwiększa ryzyko rozwoju chorób sercowo-naczyniowych (nadciśnienia tętniczego, choroby niedokrwiennej serca, zaburzeń rytmu i przewodzenia, niewydolności serca i udaru mózgu), które również znamiennie częściej współwystępują z łuszczycą [24, 25]. Zaburzenia te są skutkiem hipoksji oraz przebudzeń ze snu, które wpływają na zmianę szlaków fizjologicznych, co prowadzi do pobudzenia układu współ- 
Table 2. AASM criteria of obstructive sleep apnea syndrome

Tabela 2. Kryteria AASM służące do rozpoznania zespołu obturacyjnego bezdechu sennego

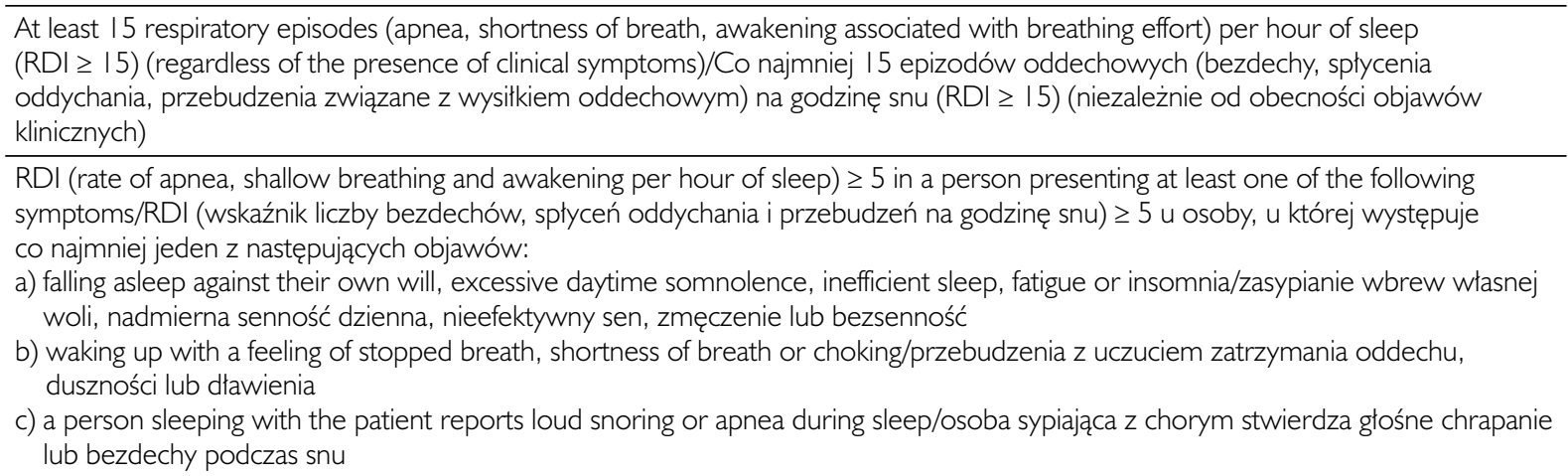

leading to stimulation of the sympathetic nervous system, oxidative stress and endothelial dysfunction [25]. In addition, as associated with daytime sleepiness, the disorder is associated with an increased risk of traffic accidents [24]. Numerous studies confirm a higher incidence of OSAS in patients with psoriasis [14]. It is postulated that psoriasis may be a separate risk factor of OSAS. However, this relationship is bidirectional, because OSAS, perceived as a systemic inflammatory disorder, is associated with hypoxia, generation of reactive oxygen species, promotion of proinflammatory cytokines, abnormal secretion of adipokines and activation of the hypothalamic-pituitary-adrenal axis, all increasing severity of psoriasis [26]. At the same time, it should be remembered that patients with psoriasis more often suffer from obesity, therefore they are more predisposed to OSAS [15]. Therefore, on medical appointments with patients with psoriasis, it seems advisable to assess the risk of OSAS, which can easily be done using the aforementioned questionnaires. Then, it is important to refer people at high risk to appropriate specialists to confirm the diagnosis and to implement an appropriate treatment, because the disorder significantly increases the incidence of cardiovascular diseases and mortality of patients [24, 25].

\section{RESTLESS LEGS SYNDROME}

Restless legs syndrome is an increasingly recognized disorder that occurs during night rest. Its prevalence is estimated at $3.9-15 \%$ in the general population. According to the guidelines of the International Restless Legs Syndrome Study Group 2012, RLS can be diagnosed when all the following criteria are met: (1) the compulsion to move the lower limbs, typically, though not always, associated with - or induced by - discomfort or unpleasant sensations in the lower limbs, (2) the compulsion to move or unpleasant sensations are revealed or intensified during rest or czulnego, stresu oksydacyjnego oraz dysfunkcji śródbłonka [25]. W związku z powodowaniem senności dziennej OSAS jest powiązany ze zwiększonym ryzykiem spowodowania przez pacjenta wypadku drogowego [24]. Liczne badania potwierdzają większą zapadalność na OSAS u chorych na łuszczycę [14]. Postuluje się, że łuszczyca może stanowić odrębny czynnik ryzyka wystąpienia OSAS. Zależność ta jest jednak obukierunkowa, gdyż OSAS ma charakter układowego zapalenia i wiąże się z hipoksją, generowaniem reaktywnych form tlenu, promocją cytokin prozapalnych, nieprawidłowym wydzielaniem adipokin i aktywacją osi podwzgórze-przysadka-nadnercza, co wpływa na nasilanie łuszczycy [26]. Należy pamiętać, że pacjenci z łuszczycą częściej są otyli, dlatego są bardziej predysponowani do zachorowania na OSAS [15]. Podczas wizyt lekarskich celowa jest ocena ryzyka wystąpienia OSAS u chorych na łuszczycę. Ocenę można z łatwością przeprowadzić za pomocą wyżej wymienionych kwestionariuszy. Następnie ważne jest skierowanie osób o wysokim ryzyku do odpowiednich specjalistów w celu potwierdzenia rozpoznania i wdrożenia leczenia, gdyż zaburzenie to istotnie zwiększa zapadalność na choroby układu sercowo-naczyniowego i śmiertelność chorych $[24,25]$.

\section{ZESPÓŁ NIESPOKOJNYCH NÓG}

Zespół niespokojnych nóg jest coraz częściej rozpoznawanym zaburzeniem pojawiającym się w okresie spoczynku nocnego. Częstość jego występowania szacuje się na 3,9-15\% w populacji ogólnej. Zgodnie z wytycznymi International Restless Legs Syndrome Study Group 2012 RLS można rozpoznać w przypadku spełnienia wszystkich następujących kryteriów: (1) przymus poruszania kończynami dolnymi, połączony zazwyczaj, choć nie zawsze, z dyskomfortem lub nieprzyjemnymi odczuciami w kończynach dolnych lub wywołany przez nie, (2) przymus poruszania lub nieprzyjemne odczucia pojawiają się lub nasilają podczas odpoczynku lub bezruchu, tj. siedzenia lub leżenia, (3) przymus poruszania lub nieprzyjemne odczucia częściowo lub całkowi- 
stillness, i.e. sitting or lying down, (3) the compulsion to move or unpleasant sensations partially or completely disappear during movement, e.g. walking and stretching, at least for as long as these activities last, (4) the compulsion to move or unpleasant sensations increase in the evening and at night compared to day or occur only in the evening or at night, (5) the occurrence of the above features is not only the primary symptom of another medical or behavioral condition (e.g. myalgia, venous stasis, edema of the lower limbs, arthritis, leg cramps and others) [22] (table 3). There are two types of RLS: primary - idiopathic - of unknown cause, and secondary - with underlying disorders, usually neurological, iron deficiency or pregnancy. Changing lifestyle, eliminating iron deficiency and drugs, primarily dopaminergic, play a major role in therapy [22]. There are reports that the incidence of RLS among patients with psoriasis is even higher than in the general population $[14,27]$, as well as in patients with psoriatic arthritis compared to patients with sole skin involvement [28]. Both psoriasis and RLS are more often observed in women, however, in the group of patients with psoriasis who simultaneously suffer from RLS, no dominance of either sex is found [28]. Some studies also report that the age of onset of RLS symptoms is lower among psoriasis patients compared to healthy individuals [29]. There is a positive correlation between the Dermatology Life Quality Index (DLQI) and RLS, while at the same time, surprisingly, there is no relationship between severity of psoriatic lesions on the PASI scale and RLS, although there are reports of higher intensity of RLS in patients with psoriasis compared to healthy individuals $[27,29]$. In practice, during medical visits, it seems justified to deepen the history of RLS symptoms, and even to assess all five classification criteria of the syndrome. However, it cie ustępują podczas ruchu, np. chodzenia i rozciągania, przynajmniej na tak długo, jak trwają te czynności, (4) przymus poruszania lub nieprzyjemne odczucia nasilają się wieczorem i w nocy w porównaniu z dniem lub występują tylko wieczorem lub w nocy, (5) występowanie powyższych cech nie jest wyłącznie pierwotnym objawem innego stanu medycznego lub behawioralnego (np. mialgia, zastój żylny, obrzęk kończyn dolnych, zapalenie stawów, skurcze kończyn dolnych) [22] (tab. 3). Wyróżnia się ponadto dwa rodzaje RLS: pierwotny - idiopatyczny, o nieznanej przyczynie oraz wtórny, u którego podłoża leżą zwykle zaburzenia neurologiczne, niedobór żelaza lub ciąża. W terapii główną rolę odgrywa zmiana stylu życia, wyeliminowanie niedoboru żelaza oraz leki, przede wszystkim dopaminergiczne [22]. Istnieją doniesienia, według których częstość występowania RLS u pacjentów z łuszczycą jest wyższa niż w populacji ogólnej [14, 27], a u pacjentów z łuszczycowym zapaleniem stawów wyższa niż u chorych, u których zajęta jest wyłącznie skóra [28]. Zarówno łuszczyca, jak i RLS są częstsze u kobiet, jednak wśród pacjentów z łuszczycą jednocześnie chorujących na RLS nie stwierdza się przewagi żadnej płci [28]. Niektóre badania donoszą także, że wiek wystąpienia objawów RLS jest niższy u chorych na łuszczycę w stosunku do osób zdrowych [29]. Opisywano dodatnią korelację pomiędzy wskaźnikiem jakości życia zależnej od dolegliwości skórnych (Dermatology Life Quality Index - DLQI) a RLS, a jednocześnie, co zaskakujące, nie znaleziono zależności między stopniem nasilenia zmian łuszczycowych w skali PASI a RLS. Istnieją jednak doniesienia o wyższym stopniu nasilenia RLS u chorych na łuszczycę w porównaniu z osobami bez tej choroby [27, 29]. W praktyce podczas wizyt lekarskich uzasadnione wydaje się pogłębianie wywiadu o objawy RLS, a nawet ocenę spełnienia wszystkich pięciu kryteriów klasyfikacyjnych tego zespołu. Należy jednak uwzględnić, że chorzy często nie rozumieją, że RLS jest konkretną, sprecyzowaną jednostką chorobową, dlatego nadinterpretu-

Table 3. Diagnostic criteria of restless legs syndrome (RLS) according to the International Restless Legs Syndrome Study Group 2012

Tabela 3. Kryteria rozpoznania zespołu niespokojnych nóg (RLS) zgodnie z wytycznymi International Restless Legs Syndrome Study Group 2012

Compulsion to move the lower limbs, typically, but not always, associated with - or caused by - discomfort or unpleasant sensations in the lower limbs/Przymus poruszania kończynami dolnymi, połączony zazwyczaj, choć nie zawsze, z dyskomfortem lub nieprzyjemnymi odczuciami w kończynach dolnych lub wywołany przez nie

Compulsion to move or unpleasant sensations become apparent or worsen when resting or still, i.e. sitting or lying down/Przymus poruszania lub nieprzyjemne odczucia pojawiają się lub nasilają podczas odpoczynku lub bezruchu, tj. siedzenia lub leżenia

Compulsion to move or unpleasant sensations partially or completely disappear during movement, e.g. walking and stretching, at least as long as these activities last/Przymus poruszania lub nieprzyjemne odczucia częściowo lub całkowicie ustępują podczas ruchu, np. chodzenia i rozciągania, przynajmniej tak długo, jak trwają te czynności

Compulsion to move or unpleasant sensations increase in the evening and at night compared to day or only occur in the evening or at night/Przymus poruszania lub nieprzyjemne odczucia nasilają się wieczorem i w nocy w porównaniu z dniem lub występują tylko wieczorem lub w nocy

Occurrence of the above features is not only the primary symptom of another medical or behavioral condition (e.g. myalgia, venous stasis, swelling of the lower limbs, arthritis, leg cramps and others)/Występowanie powyższych cech nie jest wyłącznie pierwotnym objawem innego medycznego lub behawioralnego stanu (np. mialgia, zastój żylny, obrzęk kończyn dolnych, zapalenie stawów, skurcze kończyn dolnych i inne) 
should be borne in mind that patients often do not understand that RLS is a specific, definite disease, and thus, they over-interpret their symptoms. In the case of a justified suspicion that the patient suffers from RLS, interdisciplinary cooperation of doctors is recommended to confirm the diagnosis and to determine whether the disorder is idiopathic or secondary (then it will be necessary to deepen the diagnosis for the primary cause).

\section{SUMMARY}

The incidence of various types of sleep disorders in patients with psoriasis is higher than in the general population. This emphasizes the need to perform screening in this direction, especially since they are, in most cases, easy to carry out and do not generate high costs, and at the same time they will allow identification of people who require medical help and psychological support. Effective therapy of sleep disorders will certainly improve the quality of life of patients and reduce the severity of accompanying stress and its negative impact on the course of psoriasis.

\section{CONFLICT OF INTEREST}

The authors declare no conflict of interest. ją swoje objawy. W przypadku uzasadnionego podejrzenia, że u chorego występuje RLS, wskazana jest współpraca interdyscyplinarna lekarzy w celu potwierdzenia diagnozy i ustalenia, czy zaburzenie ma charakter idiopatyczny czy wtórny (wówczas konieczne jest pogłębienie diagnostyki w celu ustalenia pierwotnej przyczyny).

\section{PODSUMOWANIE}

Częstość występowania różnego rodzaju zaburzeń snu u pacjentów z łuszczycą jest większa niż w populacji ogólnej. Powoduje to potrzebę wykonywania u chorych badań przesiewowych w tym kierunku, zwłaszcza że są one w większości przypadków łatwe do przeprowadzenia i nie generują wysokich kosztów, a pozwalają zidentyfikować osoby wymagające pomocy medycznej i wsparcia psychologicznego. Skuteczna terapia zaburzeń snu z pewnością poprawi jakość życia pacjentów i zmniejszy nasilenie towarzyszącego im stresu oraz jego negatywny wpływ na przebieg łuszczycy.

\section{KONFLIKT INTERESÓW}

Autorzy nie zgłaszają konfliktu interesów.

\section{References \\ Piśmiennictwo}

1. Baran A., Kiluk P., Myśliwiec H., Flisiak I.: The role of lipids in psoriasis. Dermatol Rev 2017, 104, 619-635.

2. Henry A.L., Bundy C., Kyle S.D., Griffiths C.E.M., Chisholm A.: Understanding the experience of sleep disturbance in psoriasis: a qualitative exploration using the Common-Sense Model of Self-Regulation. Br J Dermatol 2019, 180, 1397-1404.

3. Hawro T., Hawro M., Zalewska-Janowska A., Weller K., Metz M., Maurer M.: Pruritus and sleep disturbances in patients with psoriasis. Arch Dermatol Res 2020, 312, 103-111.

4. Salman A., Yucelten A.D., Sarac E., Saricam M.H., Perdahli-Fis N.: Impact of psoriasis in the quality of life of children, adolescents and their families: a cross-sectional study. An Bras Dermatol 2018, 93, 819-823. 
5. Rapp S.R., Feldman S.R., Exum M.L., Fleischer A.B. Jr, Reboussin D.M.: Psoriasis causes as much disability as other major medical diseases. J Am Acad Dermatol 1999, 41, 401-407.

6. Reich A., Adamski Z., Chodorowska G., Kaszuba A., Krasowska D., Lesiak A., et al.: Psoriasis. Diagnostic and therapeutic recommendations of the Polish Dermatological Society. Part 1. Dermatol Rev 2020, 107, 92-108.

7. Gałecki P., Szulc A.: Zespoły behawioralne związane z zaburzeniami fizjologicznymi i czynnikami fizycznymi. [In:] Psychiatria. P. Gałecki, A. Szulc (eds.). Edra Urban\&Partner, Wrocław, 2018, 279-324.

8. Thorpy M.J.: Classification of sleep disorders. Neurotherapeutics 2012, 9, 687-701.

9. Stenholm S., Head J., Kivimäki M., Magnusson Hanson L.L., Pentti J., Rod N.H., et al.: Sleep duration and sleep disturbances as predictors of healthy and chronic disease-free life expectancy between ages 50 and 75: a pooled analysis of three cohorts. J Gerontol A Biol Sci Med Sci 2019, 74, 204-210.

10. Drakatos P., Ghiassi R., Jarrold I., Harris J., Abidi A., Douiri A., et al.: The use of an online pictorial Epworth Sleepiness Scale in the assessment of age and gender specific differences in excessive daytime sleepiness. J Thorac Dis 2015, 7, 897-902.

11. Hurlston A., Foster S.N., Creamer J., Brock M.S., Matsangas P., Moore B.A., et al.: The Epworth Sleepiness Scale in service members with sleep disorders. Mil Med 2019, 184, e701-e707.

12. Pilz L.K., Keller L.K., Lenssen D., Roenneberg T.: Time to rethink sleep quality: PSQI scores reflect sleep quality on workdays. Sleep 2018, 41. doi: 10.1093/sleep/zsy029.

13. Hirotsu C., Rydlewski M., Araujo M.S., Tufik S., Andersen M.L.: Sleep loss and cytokines levels in an experimental model of psoriasis. PLoS One 2012, 7, e51183.

14. Gupta M.A., Simpson F.C., Gupta A.K.: Psoriasis and sleep disorders: a systematic review. Sleep Med Rev 2016, 29 , 63-75.

15. Ryan C., Kirby B.: Psoriasis is a systemic disease with multiple cardiovascular and metabolic comorbidities. Dermatol Clin 2015,33 , 41-55.

16. Shutty B.G., West C., Huan K.E., Landis E., Dabade T., Browder B.: Sleep disturbances in psoriasis. Dermatol Online J $2013,19,1$.

17. Melikoglu M.: Sleep quality and its association with disease severity in psoriasis. Eurasian J Med 2017, 49, 124-127.

18. Jensen P., Zachariae C., Skov L., Zachariae R.: Sleep disturbance in psoriasis: a case-controlled study. Br J Dermatol 2018, 179, 13761384.

19. Irwin M.R., Olmstead R., Carroll J.E.: Sleep disturbance, sleep duration, and inflammation: a systematic review and meta-analysis of cohort studies and experimental sleep deprivation. Biol Psychiatry 2016, 80, 40-52.

20. Kaaz K., Szepietowski J.C., Matusiak Ł.: Sleep quality among adult patients with chronic dermatoses. Adv Dermatol Allergol 2019, 36, 659-666

21. Krajewska-Włodarczyk M., Owczarczyk-Saczonek A., Placek W.: Sleep disorders in patients with psoriatic arthritis and psoriasis. Reumatologia 2018, 56, 301-306.

22. Guo S., Huang J., Jiang H., Han C., Li J., Xu X., et al.: Restless legs syndrome: from pathophysiology to clinical diagnosis and management. Front Aging Neurosci 2017, 9, 171.

23. Koo J.: Population-based epidemiologic study of psoriasis with emphasis on quality of life assessment. Dermatol Clin 1996, 14 , 485-496.

24. Pływaczewski R., Niżankowska-Jędrzejczyk A., Mejza F.: Obturacyjny bezdech senny (OBS). [In:] Interna Szczeklika 2017/18 Mały podręcznik. E. Niżankowska-Mogilnicka, R. Krenke (eds). Medycyna Praktyczna, Kraków, 2017.

25. Bronkowska M., Gołecki M., Słomian J., Mikołajczak J., Kosacka M., Porębska I.: Wiedza żywieniowa oraz wybrane elementy stylu życia otyłych osób z rozpoznanym obturacyjnym bezdechem w czasie snu. Rocz Panstw Zakl Hig 2010, 61, $317-322$.

26. Papadavid E., Dalamaga M., Vlami K., Koumaki D., Gyftopoulos S., Christodoulatos G.S., et al.: Psoriasis is associated with risk of obstructive sleep apnea independently from metabolic parameters and other comorbidities: a large hospital-based case-control study. Sleep Breath 2017, 21, 949-958.

27. Schell C., Schleich R., Walker F., Yazdi A.S., Lerche H., Röcken M., et al.: Restless legs syndrome in psoriasis: an unexpected comorbidity. Eur J Dermatol 2015, 25, 255-260.

28. Sandikci S.C., Colak S., Aydoğan Baykara R., Öktem A., Cüre E., Omma A.: Evaluation of restless legs syndrome and sleep disorders in patients with psoriatic arthritis. Z Rheumatol 2019, 78, 987-995.

29. Amanat M., Salehi M., Rezaei M.: Neurological and psychiatric disorders in psoriasis. Rev Neurosci 2018, $29,805-813$.

Received: 20.02 .2020

Accepted: 21.05 .2020

Otrzymano: 20.02.2020 r.

Zaakceptowano: 21.05.2020 r.

How to cite this article

Nowowiejska J., Baran A., Flisiak I.: Sleep disorders in psoriasis. Dermatol Rev/Przegl Dermatol 2020, 107, $273-280$.

DOI: https://doi.org/10.5114/dr.2020.97780. 